\title{
The Effect of Place-Based Education Integrated Project Studies on Students' Problem-Solving and Social Skills
}

\author{
Yavuz Akbaş ${ }^{1}$ \\ Safiye Çakmak ${ }^{2}$
}

'Trabzon University, Department of Turkish and Social Sciences Education, Trabzon, Turkey

Email:yakbas@trabzon.edu.trTel: +904623776710

- Social Studies Teacher, Kutahya, Turkey

Email:safivecakmak6143@outlook.comTel:+902746154674

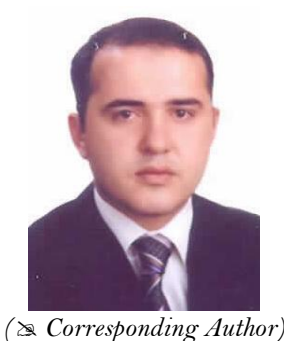

Abstract

The purpose of this study was to examine the effect of place-based education integrated project studies on students' problem solving and social skills. The participants were 18 (10 females and 8 males) 7th grade students located in a northeastern city of Turkey in the 2017 fall semester. Students conducted project studies about local history, cultural, and socio-economic structure of their environments within the context of place-based education approach. To collect data, Social Skills Scale to measure social skill levels of students and Perception Scale for Problem Solving Skills to measure students' problem solving skills were used as pre- and post-tests. Since the study was conducted with only experimental group, simple experimental design was utilized. To analyze data, SPSS package program was used. Wilcoxon signed tests were used to determine whether there was a significant difference between the pre- and post-tests mean scores of the students' problem solving and social skills. The results of the Wilcoxon signed tests revealed that students' problem solving and social skills post-test scores were significantly higher than their problem solving and social skills pre-test scores. Therefore, it can be suggested that project studies within the context of place-based education approach should be included in the teaching of different skills, values, and knowledge within the scope of social studies. For future research, it can be recommended to conduct research studies investigating the effects of project-based learning integrated project studies or activities on students' skills including communication, social inclusion, observation, and inquiry skills in social studies.

Keywords: Place-based education, Project studies, Social studies, Problem solving skills, Social skills, Simple experimental design.

Citation | Yavuz Akbas; Safiye Cakmak (2019). The Effect of PlaceBased Education Integrated Project Studies on Students' ProblemSolving and Social Skills. Asian Journal of Education and Training, 5(1): 183-192.

History:

Received: 26 November 2018

Revised: 24 December 2018

Accepted: 31 January 2019

Published: 5 March 2019

Licensed: This work is licensed under a Creative Commons Attribution 3.0 License (cc)

Publisher: Asian Online Journal Publishing Group
Contribution/Acknowledgement: Both authors contributed to the conception and design of the study.

Funding: This study received no specific financial support

Competing Interests: The authors declare that they have no conflict of interests.

Transparency: The authors confirm that the manuscript is an honest, accurate, and transparent account of the study was reported; that no vital features of the study have been omitted; and that any discrepancies from the study as planned have been explained.

Ethical: This study follows all ethical practices during writing.

\section{Contents}

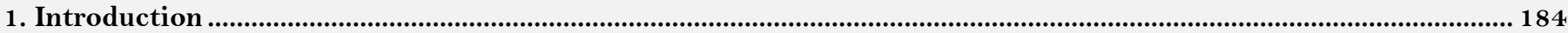

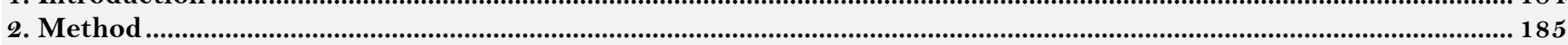

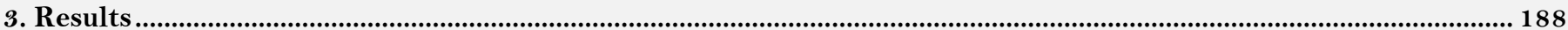

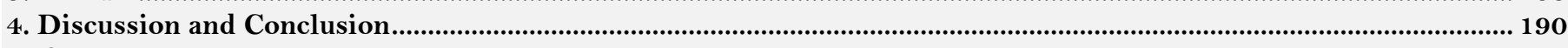

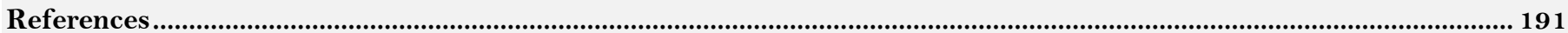




\section{Introduction}

Place-based education has been expressed in different ways. Russell-Ciardi (2006) described this approach as an educational approach that uses a local environment for teaching and learning. In this approach, the history of society and environment, folk culture, social problems, economy, and aesthetics are on the agenda (Sobel, 2004). This approach focuses on learning experiences that give students the opportunity to do valuable work, and integrate local problems and knowledge into the curriculum (Smith and Sobel, 2011). In the literature, different names such as "outdoor education," "environmental education," "awareness of the place," "ecological education," and "the pedagogy of the place" have been used for this approach (Woodhouse and Knapp, 2000). The names and definitions used for this approach emphasize the coexistence of place, environment, local history, culture, and activities of education. Some of the features in the literature about place-based education include that this approach (a) gives students different meanings about their place, (b) takes its source from the characteristics/dynamics of a place (e.g., geographical, political, and sociological), (c) encourages students to develop knowledge instead of using the knowledge, (d) increases the permeability of boundaries between schools and society, (e) is multidisciplinary and interdisciplinary although the concept of the place originates from the geography discipline (Woodhouse and Knapp, 2000; Smith, 2002; Sobel, 2004). Within the context of place-based education, educators have developed different materials and applications for the subjects, concepts, and skills to be taught in the inside and outside of the classroom. The learning process in place-based education (a) takes place in the schoolyard, local culture and the environment, (b) focuses on local themes, systems and content, (c) is personally related to the students, and (d) takes care to contribute to the power and environmental quality of the community as a result of experiences. In addition, project-based learning is supported by strong local organizations and various partnerships such as nongovernmental organizations, government agencies, and business enterprises. Project-based learning helps people develop their love for the place they live in and support understanding and solving the regional and global problems (Barnett, 2009). The objectives and practices of place-based education can be linked to experimental learning, contextual learning, problem-based learning, constructivism, outdoor education, environment and ecological education, biological education, democratic education, multicultural education, community-based education, and critical education (Gruenewald, 2003). Many of the issues related to this approach are covered in the social studies courses.

Social studies course is an interdisciplinary course and main objectives of this course contain enabling students to have the basic knowledge, skills, and values that allow students to adapt to the environment and society they live in. Therefore, attention should also be paid to the use of out-of-school environments in the teaching of this course. These teachings can be focused on schools' immediate surroundings (e.g., schoolyard), local market places, official offices, factories, exhibitions, archaeological excavations, workshops, museums and historical sites (e.g., historical buildings, monuments, museum-cities, battlefields, and virtual museum trips). In addition, oral history and local history studies should be done in appropriate subjects (Milli Ĕgitim Bakanlığı (MEB), 2018). In this context, the common points of the place-based education approach and social studies course are to offer a multidisciplinary perspective, and to help students understand different natural environments and social structures from the nearby environment they live into the global scale. Thus, it can be said that social studies education and place-based education complement each other (Resor, 2010; Akkaya, 2014) because "place-based education is the process of using the local community and environment as a starting point to teach concepts in social studies and other subjects across the curriculum. Emphasizing hands-on, real-life learning experiences, this approach increases academic achievement, helps students develop stronger ties to the community, enhances students' appreciation for the natural world, and creates an improved commitment to serving as active, contributing citizens" Sobel (2004) cited in Shannon and Galle (2017). Additionally, project-based education practices play a crucial role in identifying the problems that students are aware of where they live. Students choice a problem as the main focus, examine its characteristics, develop possible solutions, and then try to solve the problem in an organized way (Smith, 2002).

Especially in social studies courses, it is seen that students are more sensitive to the problems of the society they live in and they are more active in the society when place-based education approach is used. Drawing the attention of the students to the problems of the environment they are in, analyzing these problems, asking them to find the causes of these problems, asking them to produce solutions to these problems, not only will develop the sense of responsibility in the students, will also improve their problem solving skills (Evans and Kılınç, 2013). One of the important skills that students should gain is problem-solving in social studies course. By taking advantage of the events inside and outside of the school, students often should be faced with real-life problems and conflicting situations, and they should be reflective about the social problems they face (MEB, 2018). A community that is (a) well aware of the problem-solving mechanism, (b) ready to unite their energies for the sake of solving society's problems, and (c) determined to leverage mobilizing situations to cultivate well-developed individuals, meaning that the community is doing a purposeful preparation to meet the needs of a continually changing and evolving civilization. The main purpose of teaching the problem solving method is to let students gain the ability to cope with the problems in real life (Aksoy, 2003).

As problem solving skills, social skills are another skill that should be gained by students who try to be socialized in social studies courses. People as members of the community should also have some skills to establish good relationships with the society in which they live. The skills used to establish good relationships with the society are called social skills. The more people establish good relationships, the more they feel belonging to the community (Ozsarı, 2015). According to Elliott and Gresham (1993) social skills "are a socially acceptable behavior that makes possible for an individual to interact with others in a way that will help her/him to create positive reactions and avoid from negative reactions (cited in Tuncel (2006)). Our society needs rational and qualified individuals to compete with modern societies. Educators in education have critical responsibilities in the preparation of these individuals. To do so, there is a need to change traditional teacher-centered education methods. It is expected that students learn the information in the process of education with the abilities they acquire from their environment and their innate abilities through social interactions (Unal and Celikkaya, 2009). In this sense, place-based education approach in social studies can provide students opportunities to learn about their 
close environments better and create a perspective that can offer easier solutions to the problems they face. In this approach, students can be more sensitive to the problems of their society.

In a national research study on place-based education, Köşker (2012) conducted a qualitative study in which the researcher interviewed geography teachers about place-based education to identify geography teachers' thoughts about the place-based education approach. In another study, Akkaya (2014) measured students' academic achievements with project-based education practices. Evans and Kılınç (2013) conducted a study on the development and scope of place-based education approach in social studies. In another study by Mentiş and Ozkaral (2015), they explored place-based education approach in 4th and 5th grade social studies books. Additionally, Yildiz and Mentis (2015) examined place-based education approach in the 1st, 2nd and 3rd grade life science programs.

In international literature, there are more research studies in place-based education comparing to the national literature. In some of these studies, researchers carried out studies about students' feeling of place and how to improve students' feeling of place (Cook, 2009; Tanzer, 2011; Goldfinopoulos, 2012; Metzger, 2013). Some researchers examined the content, application areas, developmental stages and examples of place-based education programs (Tatistcheff, 2009; Resor, 2010; Sloan, 2014; Sugg, 2015; Albracht, 2016; Deringer, 2016; Madden, 2016). Some researchers conducted studies on the development of environmental awareness and environmental sustainability through a place-based education approach (Litz, 2010; Zandvliet, 2012; Zimmerman and Land, 2014). In addition, Bartholomaeus (2006) examined how place-based education used in some rural schools in Australia. In his study, Hankins (2015) investigated the roles of the school principals in place-based education practices. Preston (2015) compared a place-based education approach and geography education. Nolan (2015) explored the effects of place-based education on new ways of thinking. Ontong and Grange (2015) studied the sense of place in the South African countryside.

When literature on place-based education is examined, it can be seen that studies examining the effectiveness of the place-based education approach in social studies education is limited. Our literature review revealed that currently there is no study about the effect of place-based education integrated project studies on students' problem solving and social skills. To address gaps in the literature, in this study, the effect of place-based education integrated project studies on 7 th grade students' problem solving and social skills were investigated.

\section{Method}

\subsection{Research Design}

In this study, simple experimental design was used. In recent years, some studies have been utilized simple experimental design without a control group. Such studies follow the development of the subject or sample in terms of various variables (Cepni, 2010). The simple experimental design measures the dependent variable in a group (Cohen and Manion, 1994). In this design, participants receive a pre-test measure before the treatment and post-test measure after the treatment (Cavlazoglu and Stuessy, 2018) and the effect of the treatment is measured based on the differences between pre- and post-tests (Yılar, 2015). Since the study was conducted with only an experimental group, the simple experimental design was utilized.

\subsection{Participants}

The participants in this study were 18 (10 females and 8 males) middle school 7 th grade students located in a northeastern city of Turkey in the 2017 fall semester. The participants were chosen by purposeful sampling method since this method provides a depth examination of the situations and/or participants. This sampling method can be useful in explaining many phenomena and cases (Yıldırım and Şimşek, 2013). The participants (i.e., students) selected in this study were considered to be at the level of the grade that could carry out project studies related to the targeted teaching approach in this study.

\subsection{Data Collection Tools}

In this study, Social Skills Scale (SSS) developed by Tuncel (2006) to measure social skill levels of students, and Perception Scale for Problem Solving Skills (PSPSS) developed by Ekici and Balim (2013) to measure students' problem solving skills were used as pre- and post-tests. The SSS is consisted of 31 items and includes four factors. The Cronbach Alpha reliability coefficient of the SSS was found to be 0.86 (Tuncel, 2006). For this study, 57 students of the 7 th grade took the SSS and the Cronbach Alpha reliability coefficient of 31 items was found to be 0.91 .

The PSPSS is consisted of 22 items and includes two factors. In this scale, 15 items were collected under Perception for Problem Solving Skills factor while seven items were collected under the Willingness and Stability for Problem Solving Skills factor. The Cronbach Alpha reliability coefficient of the PSPSS was found to be 0.88 (Ekici and Balim, 2013). For this study, 57 students of the 7th grade took the PSPSS and the Cronbach Alpha reliability coefficient of 22 items was found to be 0.87 .

To analyze data collected in pre- and post-test SPSS package program was used. Wilcoxon signed ranks test was used to test whether the difference between the averages of the pre- and post-tests were statistically significant. As indicated in the relevant literature, non-parametric tests should be used when the number of sample size is below to 30 (Yilmaz and Yilmaz, 2005).

\subsection{Implementation Process of Place-Based Education Integrated Project Studies}

This research study was conducted in a middle school in a northeastern city in Turkey. First, detailed information about the research and purpose of the research study was shared with the school administration and the school's social studies teacher. Then, necessary approvals and permissions were obtained from the authorities and students' parents to begin the research process. Project studies took approximately 12 weeks to complete. Detailed information about the project process is explained below. 
Informing Students and Preliminary Testing (1st and 2nd week): The study process was started by giving information to the students about the study and explaining how to complete the PSPSS and SSS instruments. Next, students were asked to complete the PSPSS and SSS instruments.

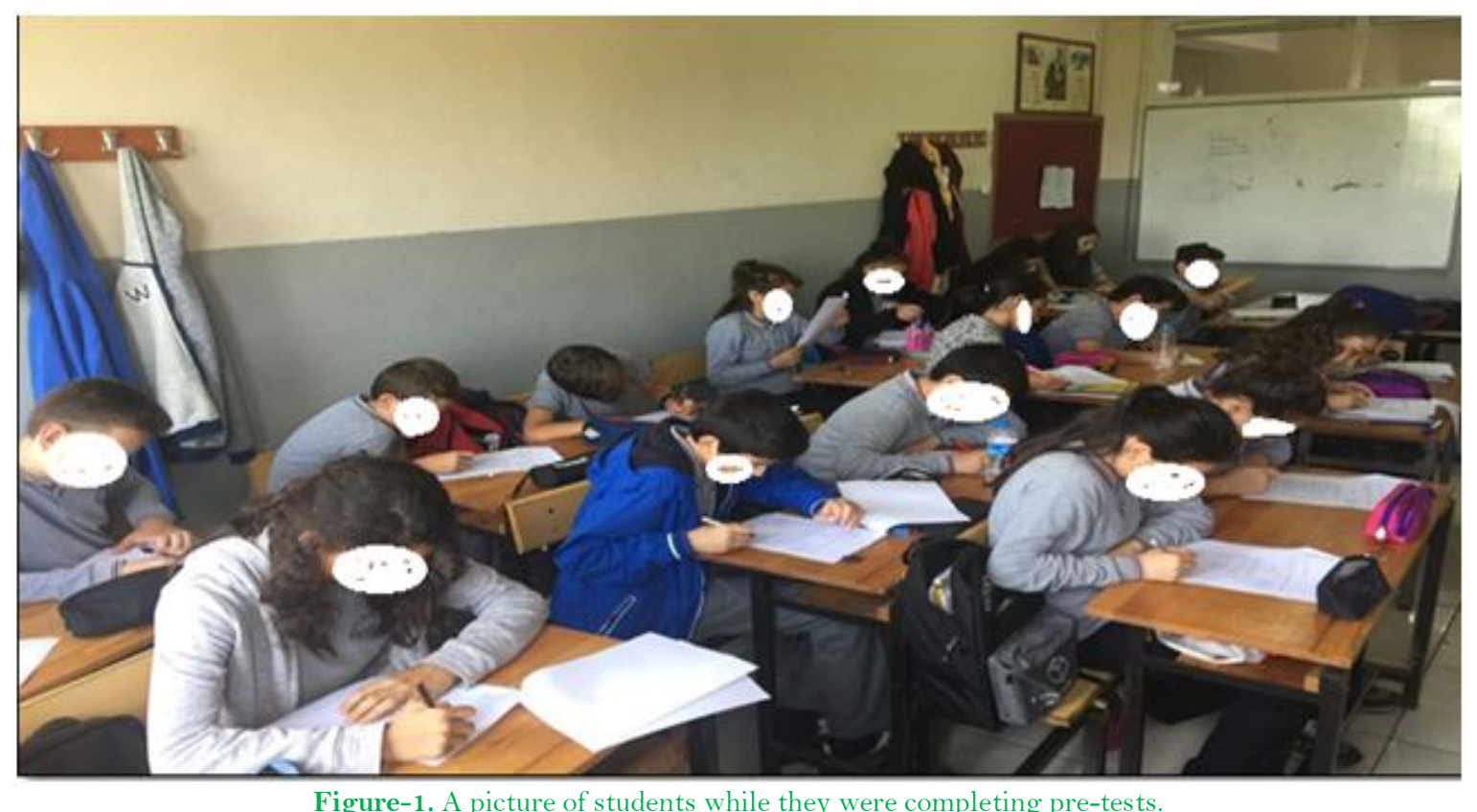

Formation of Student Groups and Determination of Project Topics (2nd week): Students were informed about the place-based education approach and the project works that they were going to carry out. Students were divided into project groups on a voluntary basis. The project groups received some project topics integrated with the placebased education approach and discussed the project topics. Student groups selected the projects they wanted to work on. The general characteristics of the place-based education approach were taken into account as it was aimed to establish a link with the place-based education approach in the selection of the student project topics. The project topics were (a) Historical Ortamahalle Houses, (b) public market, (c) fishing, (d) local culture, and (e) oral history. After the topic selection process, projects groups received project guideline and each step of the project guideline was explained.

Students' Site Visits for Projects (3rd, 4th, 5th, 6th, 7th, 8th week): The students received 6 weeks time frame to complete all processes of site visits. Each group did at least two site visits. Researchers of this study guided the student groups during their site visits. Before going to the site visits, the students prepared site visit interview questions for their interviews with the community members as indicated in the project guideline and the questions were reviewed by the researchers to make sure that the interview questions were in the line with the place-based education approach. Students did their site interviews with community members using the final form of the interview questions. In groups, each member of groups received specific responsibilities to make sure that all group work was assigned and all group members received active roles in the projects. For example, while a student asked interview questions, one student took notes, and another student took photographs and did video recording as a part of their responsibilities in a group. In this way, while students were learning how to work with a group they found opportunities to develop social skills. In addition, most of the site visits were scheduled on the weekends to make sure that students did not miss their regular classroom meetings for other subjects. More information about some of the site visits can be found below.

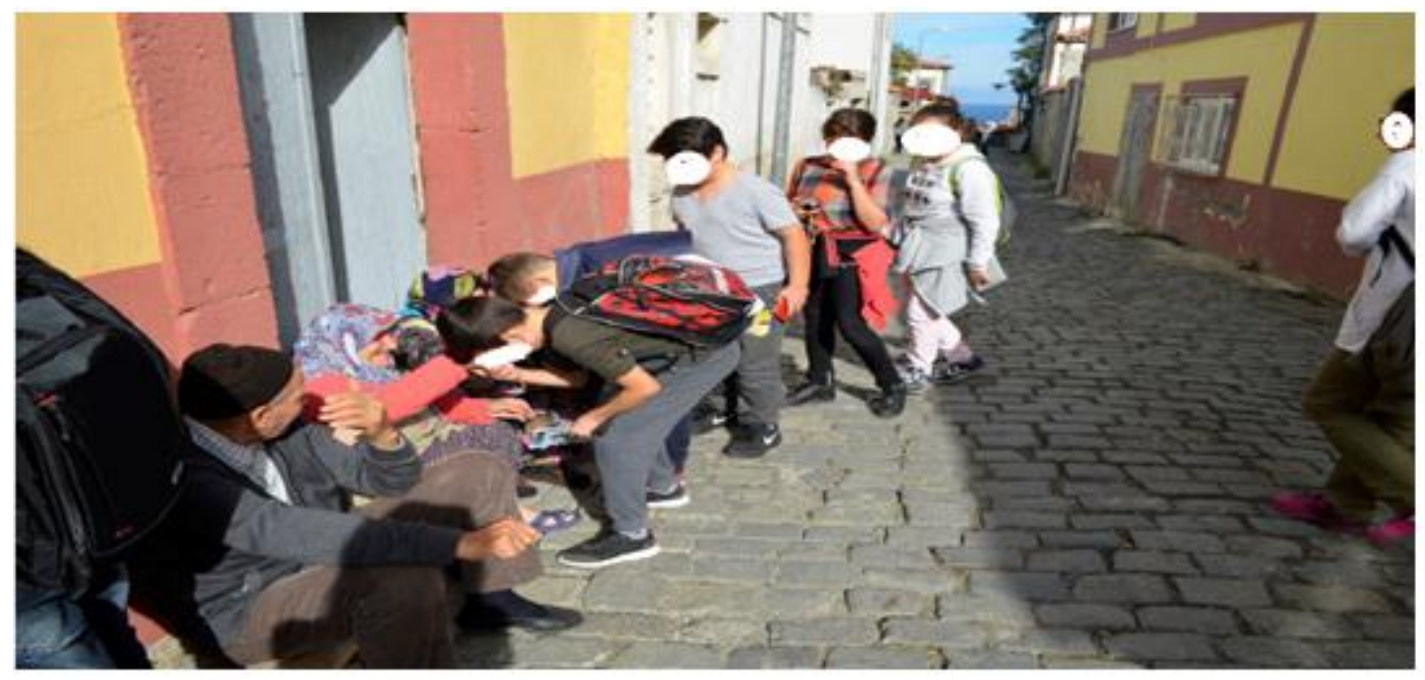

Figure-2. A picture of students visiting Historical Ortamahalle Houses.

Students in the Historical Ortamahalle Houses project group visited the place, Historical Ortamahalle Houses Neighborhood, two times for the purpose of the project. The project group students did careful observations of the historical area, interviewed residents in the Historical Ortamahalle House neighborhood, took pictures, recorded videos, and took side notes. During their visits, the students also talked with Ortamahalle Folks Association members about the history of the neighborhood and its cultural characteristics. As mentioned before, the group members divided the group work by assigning different responsibilities to each group member. 
Public market project group students visited a local public market in their neighborhood and an agriculturally active village for the purpose of the project. During their local public market visit, the project group students had opportunities to learn about different grown products in their region, interviewed local sellers including women sellers in the local public market, had a chance to learn about how the sellers, especially women sellers, made contributions to their home and district economy. The group students did interviews with sellers on different subjects such as the type of products available for sale in the market, prices of products, and agricultural activities in the local public market. The students also took pictures, recorded videos, and took side notes about the local public market. After the local public market visit in their neighborhood, the students visited a village, Kuru Cam Village, to see and examine the agricultural activities in their region. During their village visit, the students did careful observations of the agricultural area of the village, interviewed some residents in the village, took pictures, recorded videos, and took side notes. The students found opportunities to learn about the agricultural products grown in the village including kiwi and persimmon, which are some of the indigenous plants in their region.
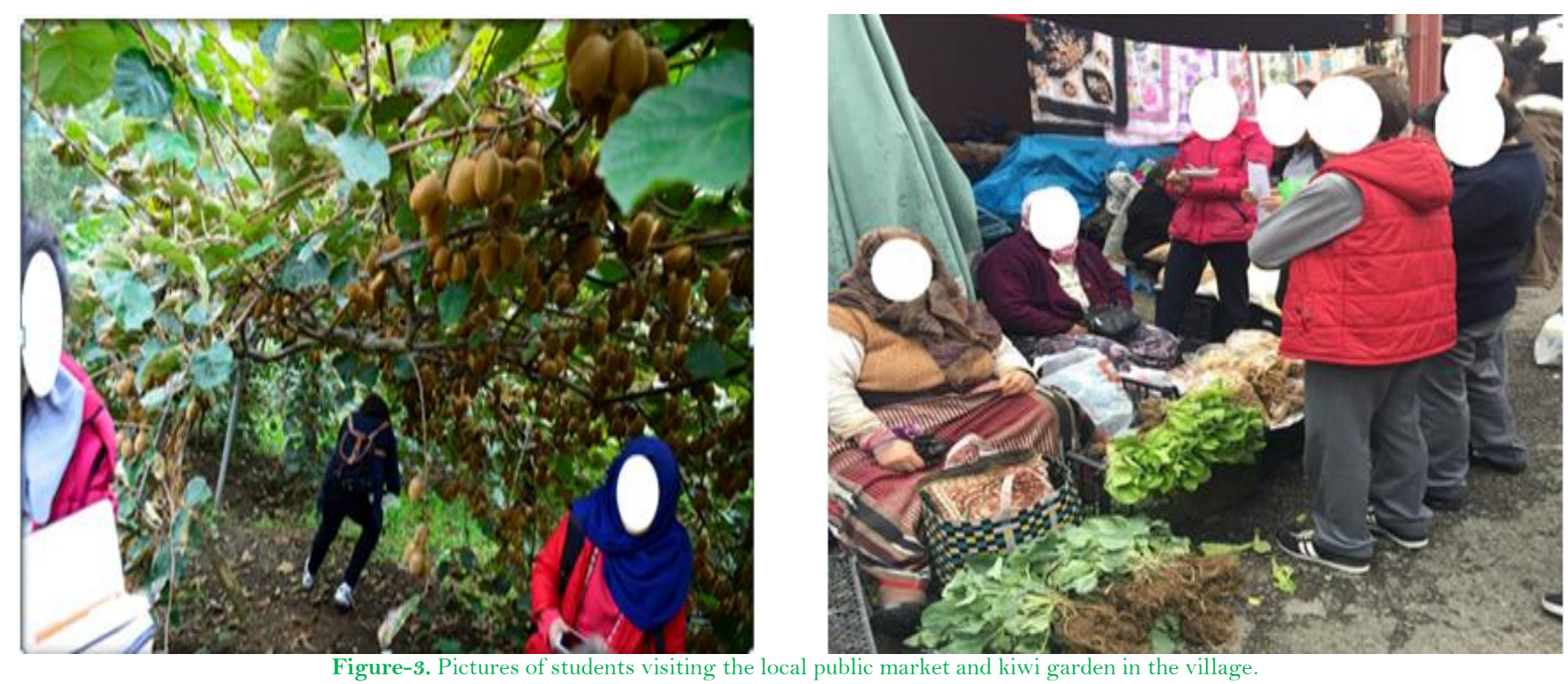

Fishing group project students visited a fishing shelter and a fishing market in their district for the purpose of the project. During these visits, the project group students interviewed about issues of fisheries, problems of fishermen, fish species, economic benefits of fishing, and contributions of fishing to the region. In their fishing market visit, the students had opportunities to make observations about different fish species that were available in their region. In addition, students did an interview with the president of Akcaabat Fishermen Association to get more information including fishing in Akcaabat region, problems of fishermen, available sea products in their region, the function of Akcaabat Fishermen Association, and economic/cultural aspects of the fishing sector. The visits allowed students to become more knowledgeable about fishing in their region.

Students in the local culture project visited a local sewing studio where traditional cloths of the region, Akcaabat, were made. In order to learn about the culture of traditional Akcaabat clothes, the students conducted an interview with the studio owner and asked about various topics such as characteristics of traditional Akcaabat clothes and folklore dressings, features of sewing styles, and economics of sewing in their region. Additionally, the students received a basic level training about traditional sewing in which they did basic fabric cuttings, made various designs of sewing patterns, and tried to use sewing machines. In this way, the students tried to gain new skills under the guidance of community members with the application of the place-based education approach. Another site visit of the local culture student group was a horon trainer. Horon is a traditional folk dance type in the Akcaabat region and has been considered one of the most important cultural elements for the region. During their horon trainer visit, students learned various information about the horon folk dance including the history of the horon in the Akcaabat region and cultural foundations of horon folk dance. Thus, this visit provided an opportunity to know the horon folk dance better.

Oral history group project students visited a village museum, a hydroelectric power station, and a local writer living in a nursing home. In their village museum visit, the students interviewed the owner of the village museum by asking various questions about the museum including the history of the museum. Students also did a museum tour with a professional guide. The students had opportunities to see various exhibitions in the museum. During their museum visit, the students took notes and pictures to be used in their project presentations. After visiting the village museum, the students visited a historical hydroelectric power station. This hydroelectric power station was country's the first hydroelectric power station which was still operating to produce electrical energy for the local region. The students learned information about hydroelectric power station from the guide in the station. The information included the history of the hydroelectric power station, general characteristics of the station, and the necessary steps for electricity production. Next, the oral history group went to a nursing home to meet with a local book writer who wrote several books about the culture of town where students were living. With the local book writer, the students talked about various topics such as culture, social characteristics, and economy of the region.

Preparation of Students' Project Presentations and Doing Presentations (9th, 10th, 11th, and 12th week): Students in the project groups were asked to prepare a presentation with the data they collected during their site visits. The source of data consisted of pictures, videos, trip notes, and audio records of interviews. Students prepared their project presentations with their group members and used pictures, videos, trip notes, voice records of interviews, and even some songs related to their projects. Each group of students presented their project works to their classmates, social studies teacher, and researchers of this study. After presentations, researchers asked students to complete the PSPSS and SSS instruments as post-tests and the data collection process was completed. 


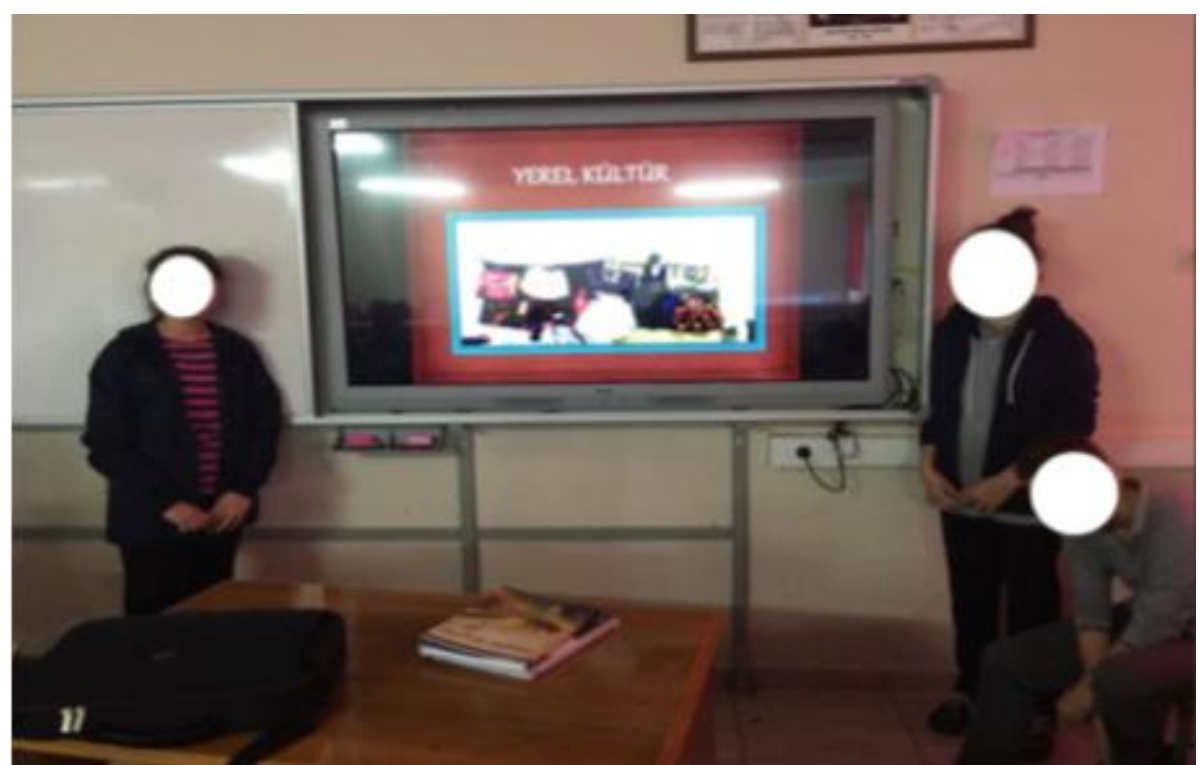

Figure-4. A picture of students presenting their group project.

\section{Results}

In this section, the results obtained from pre- and post-test of PSPSS and SSS instruments to report the effect of place-based education integrated project studies on students' problem solving and social skills are provided. In order to determine the effect of place-based education integrated project studies on students' problem solving skills, PSPSS was used as pre- and post-tests. Table 1 shows descriptive statistics of pre- and post-test of students' problem solving skills scores.

Table-1. Descriptive Statistics of Pre- and Post-Test of Students' Problem Solving Skills Scores.

\begin{tabular}{c|c|c|c|c|c}
\hline Group & N & Mean & SD & Min & Max \\
\hline Pre-test & 18 & 92.22 & 14.67 & 42.00 & 107.00 \\
\hline Post-test & 18 & 101.61 & 10.52 & 71.00 & 110.00 \\
\hline
\end{tabular}

Descriptive statistics showed that the average score of students' problem solving skills was 92.22 in the pretest and 101.61 in the post-test. These results suggest that the average score of students' problem solving skills scores increased after the project study implementation.

Wilcoxon signed test was used to determine whether there was a significant difference between the pre- and post-test mean scores of the students' problem solving skills. The results of the Wilcoxon signed test revealed that students' post-test scores of problem solving skills were significantly higher than their pre-test scores of problem solving skills (See Table 2). When ranks are taken into consideration, positive ranks were higher than negative ranks indicating that most of the post-test scores were greater than pre-test scores. These results suggest that the place-based education integrated project studies increased students' problem solving skills.

\begin{tabular}{|c|c|c|c|c|c|}
\hline Pre- and Post-test Scores & $\mathbf{N}$ & Mean Rank & Sum of Ranks & $\mathbf{z}$ & $\mathbf{p}$ \\
\hline Negative ranks & 4 & 7.25 & 29.00 & \multirow{3}{*}{-2.46} & \multirow{3}{*}{.014} \\
\hline Pozitive ranks & 14 & 10.14 & 142.00 & & \\
\hline Ties & $\mathrm{O}$ & - & - & & \\
\hline
\end{tabular}

As mentioned previously, the PSPSS instrument is consisted of two factors, (a) Perception for Problem Solving Skills and (b) Willingness and Stability for Problem Solving Skills. Wilcoxon signed test was utilized to show whether there was a significant difference between the pre- and post-test mean scores of each factor of PSPSS instrument.

Table-3. Results of Wilcoxon Signed Test between Pre- and Post-test Mean Scores of PSPSS Instrument's Each Factor.

\begin{tabular}{|c|c|c|c|c|c|c|c|}
\hline $\begin{array}{l}\text { Factor Name (Corresponding } \\
\text { Item Numbers) }\end{array}$ & \multicolumn{2}{|c|}{ Measurement } & $\mathbf{N}$ & Mean rank & $\begin{array}{c}\text { Sum of } \\
\text { ranks }\end{array}$ & $\mathbf{z}$ & $\mathbf{p}$ \\
\hline $\begin{array}{c}\text { Perception for Problem Solving } \\
\text { Skills (Items: } 1,2,3,5,7,8,10,11 \text {, } \\
\quad 12,14,16,17,19,20,22)\end{array}$ & $\begin{array}{c}\text { Post } \\
\text { test-Pre } \\
\text { test }\end{array}$ & $\begin{array}{c}\text { Negative ranks } \\
\text { Positive ranks } \\
\text { Ties } \\
\end{array}$ & $\begin{array}{c}3 \\
15 \\
0\end{array}$ & $\begin{array}{c}5.90 \\
10.88\end{array}$ & $\begin{array}{c}29.50 \\
141.50\end{array}$ & -2.444 & .015 \\
\hline $\begin{array}{c}\text { Willingness and Stability for } \\
\text { Problem Solving Skills (Items: 4, 6, } \\
\quad 9,13,15,18,21)\end{array}$ & $\begin{array}{l}\text { Post } \\
\text { test-Pre } \\
\text { test }\end{array}$ & $\begin{array}{l}\text { Negative ranks } \\
\text { Positive ranks } \\
\text { Ties }\end{array}$ & $\begin{array}{c}3 \\
14 \\
1\end{array}$ & $\begin{array}{c}12.67 \\
8.21 \\
-\end{array}$ & $\begin{array}{c}38.00 \\
115.00 \\
-\end{array}$ & -1.828 & .068 \\
\hline
\end{tabular}

Source: Calculated from primary data *Level of significance at $\mathrm{p}<0.05$.

The results of the Wilcoxon signed test for Perception for Problem Solving Skills factor showed that students' post-test scores were significantly higher than their pre-test scores (See Table 3). However, for Willingness and Stability for Problem Solving Skills factor, there was no statistically significant difference between pre- and posttest scores.

Mann-Whitney $\mathrm{U}$ test was used to determine whether there was a significant difference between females and males in the pre- and post-test mean scores of problem solving skills. The results of the Mann-Whitney U test 
indicated that there was no statistically significant difference between females and males in both pre- and post-tests mean scores of problem solving skills (See Table 4).

\begin{tabular}{c|c|c|c|c|c|c}
\multicolumn{2}{c}{ Table-4. Results of Mann-Whitney U Test between Females and Males in Pre- and Post-Tests of Problem Solving Skills Scores. } \\
\hline \multirow{2}{*}{ Measures } & Gender & N & Mean Rank & Sum of Ranks & U & p \\
\hline \multirow{2}{*}{ Pre-test } & Female & 10 & 10.40 & 104.00 & 31.00 & \multirow{2}{*}{.423} \\
\cline { 2 - 6 } & Male & 8 & 8.38 & 67.00 & \\
\hline \multirow{2}{*}{ Post-test } & Female & 10 & 7.80 & 78.00 & 23.00 & \multirow{2}{*}{.128} \\
\cline { 2 - 6 } & Male & 8 & 11.63 & 93.00 & & \\
\hline
\end{tabular}

Source: Calculated from primary data *Level of significance at $\mathrm{p}<0.05$

The mean rank of females (10.40) was higher than the mean rank of males (8.38) in the pre-test while the mean rank of males (11.63) was higher than the mean rank of females (7.80) in the post-test. Additionally, the average score of problem solving skills for females was 96.10 and 87.35 for males in the pre-test while the average score of problem solving skills for females was 98.20 and 106.25 for males in the post-test. These results suggest that the place-based education integrated project studies did not differ between females and males in developing problem solving perceptions.

In order to document the effect of place-based education integrated project studies on students' social skills, SSS was used as pre- and post-tests. Table 5 illustrates descriptive statistics of pre- and post-tests of students' social skills scores.

\begin{tabular}{c|c|c|c|c|c}
\multicolumn{6}{c}{ Table-5. Descriptive Statistics of Pre- and Post-Tests of Students' Social Skills Scores. } \\
\hline Group & $\mathbf{N}$ & Mean & SD & Min & Max \\
\hline Pre-test & 18 & 128.16 & 13.56 & 101.00 & 148.00 \\
\hline Post-test & 18 & 137.11 & 14.01 & 112.00 & 155.00 \\
\hline Source: Calculated from primary data
\end{tabular}

Descriptive statistics indicated that the average score of students' social skills was 128.16 in the pre-test and 137.11 in the post-test. These results documents that the average score of students' social skills scores increased after the project implementation.

In order to determine whether there was a significant difference between the pre- and post-test mean scores of the students' social skills, Wilcoxon signed test was used. The results of the Wilcoxon signed test detected that students' post-test scores of social skills were significantly higher than their pre-test scores of social skills (See Table 6). In addition, positive ranks were higher than negative ranks representing that most of the post-test scores were higher than pre-test scores. From the results, it can be noted that the place-based education integrated project studies increased students' social skills.

Table-6. Results of Wilcoxon Signed Test between Students' Social Skills Scores Before and After the Project.

\begin{tabular}{|c|c|c|c|c|c|}
\hline Pre- and Post-test Scores & $\mathbf{N}$ & Mean Rank & Sum of Ranks & $\bar{z}$ & $\bar{p}$ \\
\hline Negative ranks & 4 & 6.00 & 24.00 & \multirow{3}{*}{-2.68} & \multirow{3}{*}{.007} \\
\hline Positive ranks & 14 & 10.50 & 147.00 & & \\
\hline Ties & $\mathrm{O}$ & - & - & & \\
\hline
\end{tabular}

The SSS instrument is consisted of four factors including (a) Helping-Sharing, (b) Collaborative Working, (c) Independent working, and (d) Listening-Encouragement. Wilcoxon signed test was utilized to show whether there was a significant difference between the pre- and post-test mean scores of each factor of the SSS instrument.

Table-7. Results of Wilcoxon Signed Test between Pre- and Post-test Mean Scores of SSS Instrument's Each Factor.

\begin{tabular}{|c|c|c|c|c|c|c|c|}
\hline $\begin{array}{c}\text { Factor Name (Corresponding } \\
\text { Item Numbers) }\end{array}$ & \multicolumn{2}{|c|}{ Measurement } & $\mathbf{N}$ & Mean Rank & Sum of Ranks & $\mathbf{z}$ & $\mathbf{p}$ \\
\hline $\begin{array}{c}\text { Helping-Sharing (Items: 1, 2, 3, 7, 8, } \\
10,13,22)\end{array}$ & $\begin{array}{c}\text { Posttest-Pre } \\
\text { test }\end{array}$ & $\begin{array}{c}\text { Negative ranks } \\
\text { Positive ranks } \\
\text { Ties }\end{array}$ & $\begin{array}{c}3 \\
13 \\
2\end{array}$ & $\begin{array}{c}10.17 \\
8.12\end{array}$ & $\begin{array}{c}30.50 \\
105.50\end{array}$ & -1.948 & .051 \\
\hline $\begin{array}{c}\text { Collaborative Working (Items: } 5,6 \text {, } \\
9,11,12,17,19,21,24)\end{array}$ & $\begin{array}{c}\text { Posttest-Pre } \\
\text { test }\end{array}$ & $\begin{array}{l}\text { Negative ranks } \\
\text { Positive ranks } \\
\text { Ties }\end{array}$ & $\begin{array}{c}4 \\
14 \\
0\end{array}$ & $\begin{array}{c}8.38 \\
9.82 \\
-\end{array}$ & $\begin{array}{c}38,00 \\
115.00 \\
-\end{array}$ & -2.276 & .023 \\
\hline $\begin{array}{c}\text { Independent Working (Items: } 4,14 \text {, } \\
16,23,25,28,31)\end{array}$ & $\begin{array}{c}\text { Posttest-Pre } \\
\text { test }\end{array}$ & $\begin{array}{c}\text { Negative ranks } \\
\text { Positive ranks } \\
\text { Ties } \\
\end{array}$ & $\begin{array}{c}3 \\
14 \\
1 \\
\end{array}$ & $\begin{array}{c}4.33 \\
10.00 \\
- \\
\end{array}$ & $\begin{array}{c}13.00 \\
140.00 \\
- \\
\end{array}$ & -3.018 & .003 \\
\hline $\begin{array}{c}\text { Listening-Encouragement (Items: } \\
15,18,20,26,27,29,30)\end{array}$ & $\begin{array}{l}\text { Posttest-Pre } \\
\text { test }\end{array}$ & $\begin{array}{c}\text { Negative ranks } \\
\text { Positive ranks } \\
\text { Ties }\end{array}$ & $\begin{array}{c}3 \\
11 \\
4\end{array}$ & $\begin{array}{c}6.50 \\
7.77 \\
- \\
\end{array}$ & $\begin{array}{c}19.50 \\
85.50 \\
- \\
\end{array}$ & -2.102 & .036 \\
\hline
\end{tabular}

Source: Calculated from primary data *Level of significance at $\mathrm{p}<0.05$.

As seen in Table 7, the results of the Wilcoxon signed test for Collaborative Working, Independent Working, Listening-Encouragement factors revealed that students' post-test scores were significantly higher than their corresponding pre-test scores. However, for Helping-Sharing factor, there was no statistically significant difference between pre- and post-test scores.

Mann-Whitney U test was performed to detect whether there was a statistically significant difference between females and males in the pre- and post-test mean scores of social skills. The results of the Mann-Whitney U test noted that while there was no statistically significant difference between females and males in the pre-test mean scores of social skills, males' post-test mean score of social skills was statistically higher than females' post-test mean score of social skills (See Table 8). 


\begin{tabular}{c|c|c|c|c|c|c} 
Table-8. Results of Mann-Whitney U Test between Females and Males in Pre- and Post-Tests of Social Skills Scores. \\
\hline Measures & Gender & $\mathbf{N}$ & Mean Rank & Sum of Ranks & $\mathbf{U}$ & $\mathbf{p}$ \\
\hline \multirow{2}{*}{ Pre-test } & Female & 10 & 8.20 & 82.00 & \multirow{2}{*}{71.00} & \multirow{2}{.248}{} \\
\cline { 2 - 6 } & Male & 8 & 11.33 & 89.00 & & \\
\hline \multirow{2}{*}{ Post-test } & Female & 10 & 7.10 & 78.00 & \multirow{2}{*}{100.00} & $.033^{*}$ \\
\cline { 2 - 5 } & Male & 8 & 12.50 & 93.00 & & \\
\hline
\end{tabular}

The mean rank of males (11.33) was higher than the mean rank of females (8.20) in the pre-test and the mean rank of males (12.50) was higher than mean rank of females (7.10) in the post-test. In addition, the average score of social skills for males was 133.12 and 124.10 for females in the pre-test. The average score of social skills for males was 144.50 and 131.20 for females in the post-test. These results suggest that place-based education integrated project studies could be more effective for males than females in developing social skills.

\section{Discussion and Conclusion}

In this study, researchers examined the effect of place-based education integrated project studies on students' problem solving and social skills. Results on students' problem solving skills showed that the mean score of students' problem solving skills was 92.22 in the pre-test while the mean score was 101.61 in the post-test. The results also revealed that as a result of the project study implementation the level of students' problem solving skills improved significantly. The researchers of this study believe that identification of project study topics from students' close environments within the place-based education approach context and challenging students to find solutions for problems they faced during their project studies had positive impacts in cultivating their problem solving skills.

As stated in the related literature on problem solving skills, facing students with interesting real life problems, letting them collect information about problems and asking them to find solutions for the problems improve their problem solving skills. Students usually want to learn the subjects when they find subjects interesting for them (Baysal, 2005). In addition, the place-based education approach integrated project studies in teaching problemsolving skills found to be useful in providing long-term learning to students, connecting students to their places, recognizing problems in their environment and bringing solutions to the problems, encouraging students to learn by doing. In a problem based-learning research study, Erdem (2006) stated that since students learn by doing, living, making sense of the information with their individual efforts, they could make real life connections, and become long-term learners in problem based-learning environments. In another research study, Smith (2007) noted that place-based education practices allow students to closely observe the place in which they live while offering problem-solving skills and experiences that can deepen their commitment to their immediate surroundings. Smith (2002) documented that place-based education approach helps students to define problems, focus on the problems, examine the dynamics of the problems, and make efforts to solve and find potential solutions to the problems. Regarding place-based education approach projects, Smith and Sobel (2011) reported that students who were trained in placed-based education projects were more capable in problem-solving and strategic thinking than their peers who were trained in traditional education approach. The results of Kurak (2009) research study are consistent with the results of this study indicating that students develop better problem solving, decision making, creative and critical thinking skills in project studies.

In the studies conducted within the scope of the place-based education approach, students realized problems in their immediate surroundings during their researches and offered solutions to these problems. With the placebased education approach, students developed better problem solving skills while preparing interview questions, doing interviews, interacting with the community members, facing with some problems about the trips, and trying to find solutions from their points of view in the group.

In this study, results on students' social skills indicated that the mean score of students' SSS was 128.16 in the pre-test while the mean score was 137.11 in the post-test. The results also showed that as a result of the project study implementation the level of students' social skills enhanced significantly. These results suggest that the place-based education integrated project studies significantly increased students' social skills.

In the place-based education integrated project studies, asking students to create a study group, letting them work with their peers in groups, giving active responsibilities, asking them to communicate with group members, asking to find solutions to problems, letting them encourage each other in groups, and asking them collaborate in groups may improve students' social skills. In addition, group studies can be effective in developing self-confidence for students when they have the opportunity to work with groups. In a related study, Ylar (2015) indicated that when projects studies were conducted in groups, they positively affect students' social skills since students were in constant cooperation and communication with their group members in the process. In another study, Conway and Gow (1988) stated that collaborative teaching techniques with group studies were effective for inactive students with low social skills in integrating them into active learning in the class and improved students' social skills of (cited in Arısoy (2011)). Tuncel (2006) identified that working in groups motivated students each other, created a team spirit, encouraged each other, increased students' social skills as similarly found in the project group studies of this study. Parallel with the findings of this study, Yıldız et al. (2017) showed that students' collaborative works, sharing ideas, helping each other in groups enhanced their friendly relations and increased their social skills.

In project studies within the context of place-based education, students' collaborative works in groups, making decisions with group members, participating in trips, collecting data as teams, and trying to find solutions to problems together in groups may positively affect the motivation of students. In addition, interactions of introvert and shy students with group members and successful completion of group projects can improve their social and collaboration skills. In this study, it was found that the average scores of male students' social skills were higher than female students. This result suggests that male students improved their social skill better as a result of placebased education implementation in project studies. This result differs from the results of Memiş and Memiş (2013) study in which researchers examined the effect of academic achievement and age on 4th and 5th grade students' social skill levels. Memiş and Memiş (2013) found a significant difference in social skill levels with higher social 
skill levels in female students. In another research study by Keskin (2007) it was concluded that the social skill levels of 7 th grade students did not differ based on gender. In this study, working mostly outside of the school, communicating with different segments of society during the site visits, and having extrovert personalities as a result of cultural factors could support male students' development of social skills better. Therefore, male students could improve their social skills greater than female students.

In conclusion, the researchers of this study found that the place-based education integrated project studies were effective in enhancing students' problem solving and social skills in social studies. Thus, it can be suggested that projects studies within the context of the place-based education approach should be included in the teaching of different skills, values, and knowledge within the scope of social studies. For future research, it can be recommended to conduct research studies investigating the effects of project-based learning integrated project studies or activities on students' skills including communication, social inclusion, observation, and inquiry skills in social studies.

\section{References}

Akkaya, M., 2014. Place based teaching approach in social studies. Unpublished Master's Thesis. Gazi University, Institute of Educational Sciences, Ankara.

Aksoy, B., 2003. Application of problem solving method in environmental education. Pamukkale University Faculty of Education Journal, 2(14): 83-98.

Albracht, C.A., 2016. Wilderness restoration: A case study of two place based education programs. Unpublished Doctoral Dissertation. The Graduate Collage of the University, Nebraska. Retrieved from ProQuest Dissertations \& Theses Global (UMI No. 10143322).

Arısoy, B., 2011. The effect of cooperative learning on the achievement, retention and social skill levels of 6th grade students in the mathematics course of statistics and probability. University, Institute of Social Sciences, Adana, Turkey. (Unpublished Master's Thesis), Çukurova University, Institute of Social Sciences, Adana.

Barnett, S.A., 2009. Place-based education and teaching about marin county birds: Curriculum development for teachers. Unpublished Master's Thesis, Dominican University of California, San Rafael, CA.

Bartholomaeus, P., 2006. Some rural examples of place-based education. International Education Journal, 7(4): 480-489.

Baysal, Z.N., 2005. To create problem situations for problem-based learning in life science / social studies teaching. Turkish Journal of Educational Sciences, 3(4): 451-485.

Cavlazoglu, B. and C. Stuessy, 2018. Examining science teachers' argumentation in a teacher workshop on earthquake engineering. Journal of Science Education and Technology, 4(27): 348-361.Available at: https://doi.org/10.1007/s 10956-018-9728-2.

Cepni, S., 2010. Introduction to research and project work. Trabzon: Celepler Printing.

Cohen, L. and L. Manion, 1994. Research methods in education. London and New York: Routledge.

Conway, R.N. and L. Gow, 1988. Mainstreaming special class students with mild handicaps through group instruction. Remedial and Special Education, 9(5): 34-40.Available at: https://doi.org/10.1177/074193258800900508.

Cook, L.W., 2009. Developing a sense of place: Examining educator practice in place-based education. Unpublished Master's Thesis. Prescott College, Arizona. Retrieved from ProQuest Dissertations \& Theses Global (UMI No. 1462063).

Deringer, S.A., 2016. Mindful place based education :Incorporating mindfulness as a tool for place based educators. Unpublished Doctoral Dissertation. Washington State University, Washington, Retrieved from ProQuest Dissertations \& Theses Global, (UMI No. 10139e574).

Ekici, D.I. and A.G. Balim, 2013. Perception scale for problem solving skills for secondary school students: Validity and reliability study. Journal of Faculty of Education, 10(1): 67-86.

Elliott, S.N. and F.M. Gresham, 1993. Social skills interventions for children. Behavior Modification, 17(3): 287-313.Available at: https://doi.org/10.1177/01454455930173004.

Erdem, E., 2006. The effect of problem based learning on learning products, problem solving skills and self-efficacy perception level. Unpublished Doctoral Dissertation, Hacettepe University, Institute of Social Sciences, Ankara.

Evans, T.R. and E. Kılınç, 2013. History of place-based education in the social studies field. Adıyaman University Journal of Institute of Social Sciences, 6(14): 263-280.

Goldfinopoulos, K.A., 2012. Practices and potentialities of place based education in Flagstaff, Arizona: An exploratory study. (Unpublished Master's Thesis). Northern Arizona University, Arizona, USA, Retrieved from ProQuest Dissertations \& Theses Global. (UMI No.153513).

Gruenewald, D.A., 2003. The best of both worlds: A critical pedagogy of place. Educational Researcher, 32(4): 3-12.Available at: https://doi.org/10.3102/0013189x032004003.

Hankins, S.D., 2015. Leading in place: A case study of the role of public school principals in facilitating place-based learning. Unpublished Doctoral Dissertation. Ohio University, Ohio, USA, Retrieved from ProQuest Dissertations \& Theses Global (UMI No. $10024045)$.

Keskin, A., 2007. Examining the social skills of the students with the course achievement. Unpublished Master's Thesis, Celal Bayar University, Institute of Social Sciences, Manisa.

Köşker, N., 2012. Teachers' opinions on ground-based teaching approach in geography education. Unpublished Doctoral Dissertation, Gazi University, Institute of Educational Sciences, Ankara.

Kurak, D., 2009. Evaluation of project work by fourth and fifth grade students according to the views of teachers and students. Unpublished Master's Thesis, Çukurova University, Institute of Social Sciences, Adana.

Litz, L.K., 2010. Inspiring environmental stewardship: Developing a sense of place, critical thinking skills, and ecoliteracy to establish an environmental ethic of care. Unpublished Master's Thesis. Prescott College, Arizona, USA, Retrieved from ProQuest Dissertations \& Theses Global (UMI No. 1476123).

Madden, E.J., 2016. Place-based education: Educator perspectives on a critical pedagogy. Unpublished Master's Thesis. Prescott College, Arizona, USA, Retrieved from ProQuest Dissertations \& Theses Global (UMI No. 10110427).

Memiş, A. and A.U. Memiş, 2013. Gender, achievement and social skill. Karaelmas Journal of Educational Sciences, 1(1): 43-49.

Mentiş, T.A. and T.C. Ozkaral, 2015. Social studies 4-5. Evaluation of class programs and textbooks according to the place-based education approach. Bartin University Faculty of Education Journal, Special Issue on XIV. International Participation Symposium of Primary School Teacher Education (May 21-23). pp: 32-43.

Metzger, N., 2013. Educating for belonging: Place-based education for middle school students. Unpublished Master's Thesis. Prescott College, Arizona, USA, Retrieved from, ProQuest Dissertations \& Theses Global, (UMI No. 1538942).

Milli Eğitim Bakanlığg (MEB), 2018. Ministry of National Education (MNE). Social studies curriculum in Turkey. Available from http://mufredat.meb.gov.tr/ProgramDetay.aspx?PID=354.

Nolan, E.A., 2015. A phenomenological, qualitative study of place for place-based education: Toward a place-responsive pedagogy. Unpublished Doctoral Dissertation. Arizona State University, Arizona, USA, Retrieved from ProQuest Dissertations \& Theses Global, (UMI No. 3688841).

Ontong, K. and L.L. Grange, 2015. The need for place-based education in South African schools: The case of greenfields primary. Perspectives in Education, 33(3): 42-57.

Ozsarı, M.P., 2015. Examining the alienation and social skill levels of school 4th and 5th grade students in school. Unpublished Masterüss Thesis, Mehmet Akif Ersoy University, Institute of Educational Sciences, Burdur.

Preston, L., 2015. The place of place-based education in the Australian primary geography curriculum. Geographical Education, 28: 41-49.

Resor, C.W., 2010. Place-based education: What is its place in the social studies classroom? The Social Studies, 101(5): 185-188.Available at: https://doi.org/10.1080/00377990903493853. 
Russell-Ciardi, M., 2006. Place-based education in an urban environment 1. Museum International, 58(3): 71-77.

Shannon, D. and J. Galle, 2017. Where we are: Place, pedagogy, and the outer limits, Shannon D. and Galle, J (Eds.), Interdisciplinary approaches to pedagogy and place-based education. Cham, Switzerland: Springer International Publishing AG.

Sloan, C.J., 2014. Destination education: A place based look at the influences of school. Unpublished Doctoral Dissertation. University of the Pacific, California, USA, Retrieved from ProQuest Dissertations \& Theses Global, (UMI No. 3625188).

Smith, G.A., 2002. Place-based education: Learning to be where we are. African Delta Coat, 83(8): 584-594.Available at: https://doi.org/10.1177/003172170208300806.

Smith, G.A., 2007. Place-based education: Breaking through the constraining regularities of public school. Environmental Education Research, 13(2): 189-207.Available at: https://doi.org/10.1080/13504620701285180.

Smith, G.A. and D. Sobel, 2011. Place- and community-based education in schools. Environmental Education Research, 17(3): 425432.Available at: https://doi.org/10.1080/13504622.2010.548154.

Sobel, D., 2004. Place based education: Connecting classrooms and communities. Encounter: Education for Meaning and Social Justice, 17(3): 63-64.

Sugg, S.T., 2015. Place based education in a rural appalachian elementery school: A program evaluation. Unpublished Doctoral Dissertation. The College of William and Mary, Virginia, USA, Retrieved from ProQuest Dissertations \& Theses Global,(UMI No. 3663016$).$

Tanzer, E., 2011. Sense of place" development: A teacher's action research project. Unpublished Master's Thesis), Prescott College, Arizona, USA, Retrieved from ProQuest Dissertations \& Theses Global,(UMI No.1492595).

Tatistcheff, R.K., 2009. Divergent meanings of place: Two instantiations of place based curriculum in a rural school. Unpublished Doctoral Dissertation, Columbia University, New York, USA, Retrieved from ProQuest Dissertations \& Theses Global, (UMI No. 3368262).

Tuncel, Z., 2006. Effects of cooperative learning on physical education achievement, cognitive processes and social behaviors. Unpublished Doctoral Dissertation, Dokuz Eylul University, Institute of Educational Sciences, Izmir.

Unal, C. and T. Celikkaya, 2009. The effect of constructive approach on success, attitude and permanency at the social sciences teaching (5th class example). Journal of Graduate School of Social Sciences, 13(2): 197-212.

Woodhouse, J.L. and C.E. Knapp, 2000. Place-based curriculum and instruction outdoor and environmental education approaches. ERIC Document Reproduction Services No. ED 448 012. Available from https://files.eric.ed.gov/fulltext/ED4480 12.pdf.

Ylar, M.B., 2015. The effects of cooperative learning methods on their academic achievements, democratic attitudes and social skills in social studies course. Unpublished Doctoral Dissertation, Atatürk University, Institute of Educational Sciences, Erzurum.

Yıldırım, A. and H. Şimşek, 2013. Qualitative research methods in social sciences. 9th Edn., Ankara: Seckin Publishing.

Yıldız, E., Ü. Simşek and H. Agdaş, 2017. The effect of the cooperative learning model on educational motivation and social skills of the integrated cooperative learning model. Ahi Evran University Kırşehir Education Faculty Journal, 18(2): 37- 54.

Yildiz, N. and S.A. Mentis, 2015. Life science1,2 and 3rd grade program to evaluate the textbooks in terms of place-based education. International Journal of Educational Sciences, 2(5): 273-284.

Yilmaz, Y. and Y. Yilmaz, 2005. Use of nonparametric tests in marketing research: Between 1995-2002. Dokuz Eylül University Journal of the Institute of Social Sciences, 7(3): 177-199.

Zandvliet, D.B., 2012. Development and validation of the place-based learning and constructivist environment survey (PLACES). Learning Environments Research, 15(2): 125-140.Available at: https://doi.org/10.1007/s 10984-012-91 10-x.

Zimmerman, H.T. and S.M. Land, 2014. Facilitating place-based learning in outdoor informal environments with mobile computers. TechTrends, 58(1): 77-83.Available at: https://doi.org/10.1007/s11528-013-0724-3. 